\title{
THE FECUNDITY, TIME OF EGG DEVELOPMENT AND JUVENILE PRODUCTION IN SPINY-CHEEK CRAYFISH (ORCONECTES LIMOSUS) UNDER CONTROLLED CONDITIONS
}

\author{
P. KOZÁK (1), M. BUŘıČ (2), T. POLICAR (1)
}

(1) University of South Bohemia in České Budějovice, Research Institute of Fish Culture and Hydrobiology, 38925 Vodňany, Czech Republic.

E-mail: kozak@vurh.jcu.cz

(2) University of South Bohemia in České Budějovice, Faculty of Agriculture, Czech Republic.

Reçu le 30 mai 2005

Accepté le 12 janvier 2006

Received May 30, 2005

Accepted January 12, 2006

\begin{abstract}
We comprehensively describe the fecundity and time of embryonic development of the spiny-cheek crayfish (Orconectes limosus). Linear relationships between female size and ovarian fecundity, pleopodal fecundity, and production of juveniles at the $3^{\text {rd }}$ stage, were confirmed. The ovarian fecundity was evaluated for the smallest as well as largest females in the sampled population (43-93 mm of body length); the number of oocytes (eggs) ranged widely, between 46 and 505 . No significant difference was found between the ovarian and pleopodal fecundity observed just after egg laying. The value of the female gonadosomatic index just before laying was $4.2 \pm 1.8 \%(0.8-7.7 \%)$. The mean diameter of eggs on female pleopods was $1.8 \pm 0.2 \mathrm{~mm}(1.45-2.15 \mathrm{~mm})$. A statistically significant difference was found between the numbers of eggs carried on individual pairs of pleopods. Mean time from laying to hatching was $46 \pm 3.8$ days (37-56 days), i.e. $647 \pm 39.9 \mathrm{CTU}$ (Celsius Temperature Units $=$ degrees Celsius $\times$ days). Mean production of juveniles at the $3^{\text {rd }}$ stage was found to be $135.7 \pm 67.24(15-243)$ juveniles. The early sexual maturation and also high number of juveniles at the $3^{\text {rd }}$ stage per female gives this species a good predisposition for quick establishment in new localities.
\end{abstract}

Key-words: Crayfish, Orconectes limosus, lifecycle, Czech Republic, juveniles, egg development.

\section{LA FÉCONDITÉ, LA DURÉE DU DÉVELOPPEMENT EMBRYONNAIRE ET LA PRODUCTION DE JUVÉNILES CHEZ L'ÉCREVISSE AMÉRICAINE (ORCONECTES LIMOSUS) DANS UN ENVIRONNEMENT CONTRÔLÉ}

\section{RÉSUMÉ}

Cette étude décrit en détail la fécondité et la durée de développement embryonnaire de l'écrevisse américaine (Orconectes limosus) et confirme le rapport direct entre la taille de la femelle, la fécondité ovarienne, pléopodale et la production de juvéniles au stade 3. La fécondité ovarienne a été évaluée pour les femelles les plus petites aussi bien que pour les plus grandes femelles de la population échantillonnée (longueur corporelle de 43 à $93 \mathrm{~mm}$ ). Le nombre d'oocytes varie fortement, entre 46 et 505 . On n'a pas trouvé de différence 
significative entre la fécondité ovarienne et la fécondité pléopodale, observées juste après la ponte. La valeur de l'indice gonadosomatique (I.G.S.) trouvée juste avant la ponte est de $4,2 \pm 1,8 \%(0,8-7,7 \%)$ pour les femelles et de $0,3 \pm 0,05 \%(0,2-0,4 \%)$ pour les mâles. Le diamètre moyen des œufs sur les pléopodes des femelles était de $1,8 \pm 0,2 \mathrm{~mm}(1,45$ $2,15 \mathrm{~mm}$ ). Le nombre d'œufs sur les paires individuelles de pléopodes était très variable (95 à 492). La durée moyenne entre la ponte et l'éclosion était de $46 \pm 3,8$ jours (37 à 56 jours), i.e. $647 \pm 39,9^{\circ}$ Celsius $\times$ jour (543 à 730 ). La production moyenne de juvéniles au stade 3 fut de 135,7 \pm 67,24 (15 à 243) juvéniles. La maturité sexuelle plus précoce et le grand nombre de juvéniles de stade 3 produits par femelles donnent à cette espèce une prédisposition à occuper plus rapidement de nouveaux sites.

Mots-clés : Écrevisse, Orconectes limosus, cycle biologique, République tchèque, juvéniles, développement des œufs.

\section{INTRODUCTION}

The spiny-cheek crayfish (Orconectes limosus) (Rafinesque) is originally native to the east coast of the USA and Canada (HOBBS, 1974; HAMR, 2002). This species was imported to Europe in 1891. Nowadays, it is widely distributed throughout most Westernand Central European countries (HOLDICH et al., 1999). It is one of five crayfish species that are currently present in open waters of the Czech Republic. The noble crayfish Astacus astacus (Linnaeus), stone crayfish Austropotamobius torrentium (Schrank), narrow-clawed crayfish Astacus leptodactylus (Eschscholtz) and signal crayfish Pacifastacus leniusculus (Dana) are also present.

Although the first report of the presence of the spiny-cheek crayfish on the Czech territory was published at the end of the 1980's, the species seems to have been present in the river Elbe already in the 1960's. By the end of $20^{\text {th }}$ century, it had spread widely in the Elbe watershed, due to its natural dispersal potential as well as a result of anthropogenic translocations (KOZÁK et al., 2004; PETRUSEK et al., 2006). This species is a major vector of the crayfish plague pathogen, Aphanomyces astaci, in Czech open waters (KOZUBÍKOVÁ et al., 2006).

The spiny-cheek crayfish shows several characteristics such as rapid maturation, short-lifespan, high fecundity and second mating period, which facilitate its fast population growth, dispersal and invasive capabilities. In Québec populations, mating takes place in September-October and again in March-April (HAMR, 2002). According to BRINK et al. (1988), the mating period for O. limosus occurs in autumn, just as it does for $A$. astacus, A. leptodactylus and P. leniusculus. HAMR (2002) states, however, that in American and European populations mating also takes place in spring, and eggs are carried from March to May. BRINK et al. (1988) captured ovigerous females of O. limosus from mid-March to May. A similar period for egg development has been presented by PIEPLOW (1938), SMITH (1981) and ORZECHOWSKI (1984). SMITH (1981) and BRINK et al. (1988) observed that larger and presumably older females of $O$. limosus extruded their eggs earlier in the season than smaller and younger ones. A temporal difference in the onset of the breeding period between younger and older females is probably a more common phenomenon in orconectid crayfish, as it is also known for Orconectes immunis (TACK, 1941).

The potential reproductive capacity of crayfish is usually measured by ovarian egg counts, and realised reproductive capacity by pleopod egg counts. Pleopod egg counts are typically more variable and lower in total numbers than ovarian counts because of incomplete egg extrusion at spawning, eggs that fail to be fertilised, eggs that fail to attach after extrusion or because of losses of attached eggs during the incubation period for various reasons (MASON, 1977; SAVOLAINEN et al., 1996). Pleopod egg counts are more informative when determining recruitment to a population and are therefore more 
useful when management of a population is involved (LEWIS, 2002). In Austropotamobius pallipes, the ovarian fecundity differs from pleopodal egg counts by $20-40 \%$ (REYNOLDS, 2002). In White Lake (Ireland), the observed shortfall in Austropotamobius pallipes pleopodal egg number relative to ovarian fecundity was about $30 \%$, but females immediately after spawning had retained at most $2 \%$ of their eggs in ovaries or oviducts. This suggests that the discrepancy between the two measures of fecundity is chiefly due to poor egg attachment, rather than to factors such as egg resorption or incomplete fertilisation (SAVOLAINEN et al., 1996; REYNOLDS, 2002). Both ovarian and pleopodal fecundity correlated with female size (STYPIŃSKA, 1973; SAVOLAINEN et al., 1996; AUSTIN, 1998a; SCHULZ and ŚMIETANA, 2001; HARLIOĞLU et al., 2004; MAZLUM and EVERSOLE, 2004; NAKATA and GOSHIMA, 2004; HUBER and SCHUBART, 2005; MAGUIRE et al., 2005), but the relationship between the egg number and body size was strongly influenced by environmental conditions (REYNOLDS, 2002). Different authors evaluated the pleopodal fecundity just after ovulation (ABRAHAMSSON, 1971; AUSTIN, 1998a,b; LEONARD et al., 2001; NAKATA and GOSHIMA, 2004; CELADA et al., 2005a; SÁEZ-ROYUELA, 2005), during incubation (JONES, 1995; LEWIS and HORTON, 1997; MAZLUM and EVERSOLE, 2004; CELADA et al., 2005a,b; SÁEZ-ROYUELA, 2005) or just before hatching (SÖDERBÄCK, 1995; SAVOLAINEN et al., 1996; CELADA et al., 2005b; SÁEZ-ROYUELA et al., 2005).

STYPIŃSKA (1973) recorded an average ovarian fecundity of spiny-cheek crayfish from 315 to 440 eggs related to size group (body length of females ranged from 75 to $104 \mathrm{~mm}$ ). KOZÁK and POLICAR (in press) found a mean ovarian fecundity (females from 52-82 mm of body length) of 140 eggs, with a minimum of 76 and maximum of 290 eggs.

PIEPLOW (1938) observed pleopodal fecundity of 241-394 eggs in the spiny-cheek crayfish females (body length ranging from 66 to $92 \mathrm{~mm}$ ) just two days after laying. Three weeks after the laying, however, the average pleopodal fecundity values were lower - 130 eggs with a minimum and maximum of 2 and 316 eggs, respectively. HOLDICH and LOWERY (1988) presented a pleopodal fecundity of 400 eggs for a spiny-cheek crayfish female with a carapace length of $45 \mathrm{~mm}$. MOMOT in HOLDICH and LOWERY (1988), however, presented a much lower value of mean pleopodal fecundity - 163 eggs. STUCKI (2002) found a mean average pleopodal fecundity of 139 eggs with minimum and maximum 31 and 555 eggs, respectively. HAMR (2002) collected data of several authors and presented pleopodal fecundity ranging between 57 and 440 eggs.

The aim of our study was to comprehensively describe the fecundity and the time of embryonic development of the spiny-cheek crayfish under Central European conditions.

\section{MATERIAL AND METHODS}

Crayfish used in the experiment were collected on April 18 and April 26, 2004 in the Kořensko reservoir (Vltava River, South Bohemia, Czech Republic). We measured the body length, carapace length and weight of all crayfish.

\section{Ovarian and pleopodal fecundity}

Ovarian fecundity of 20 females was evaluated on April 18, just after catching. We selected individuals that represented both the smallest and largest size fractions of mature females in the sample. Total whole body wet weight of each individual was determined to the nearest $0.1 \mathrm{~g}$ on an electronic balance. Each crayfish was then dissected and its gonad was removed. The gonad was weighed on an electronic balance to the nearest $0.0001 \mathrm{~g}$. The gonadosomatic index (GSI; ratio of wet weight of ovary to the whole body 
wet weight $\times 100$ ) was calculated for each crayfish. The number of eggs in the ovaries was counted.

The laying of eggs took place at the end of April and beginning of May. Altogether, 16 females were kept in a special apparatus with shelters in a flow-through system throughout this period. Pleopodal fecundity was evaluated approximately 3 days after the laying. Eggs were removed and counted individually from each pleopod.

\section{Number of juveniles at the $3^{\text {rd }}$ stage}

Altogether, 20 females without eggs were stocked individually on April 18 in the Rückel-Vacek hatching apparatus (originally used for hatching salmonid eggs) with a flow-through system. We observed the time of egg laying, hatching and the time of juvenile independence ( $3^{\text {rd }}$ stage); observations were done only twice a week to minimize disturbance and manipulation. Just after reaching the $3^{\text {rd }}$ stage, we counted the number of juveniles.

\section{Time of embryonic development}

Altogether, 80 females were kept in 4 special apparatuses $(4 \times 20$ females $)$ with shelters in a flow-through system. Females were individually marked with a glosspaint pen by writing their individual number on the carapace (see SINT and FÜREDER, 2004). Females were checked daily to observe time of laying and subsequently time of juvenile hatching. This allowed us to record the specific time of laying and hatching, but unfortunately caused daily disturbance of females.

Water temperature and outside air temperature were measured automatically by temperature sensors RT-F52 (Qi Analytical Ltd. CZ) at one hour intervals during all experiments (Figure 1). The CTU (Celsius Temperature Units $=$ degrees Celsius $\times$ days) was calculated.

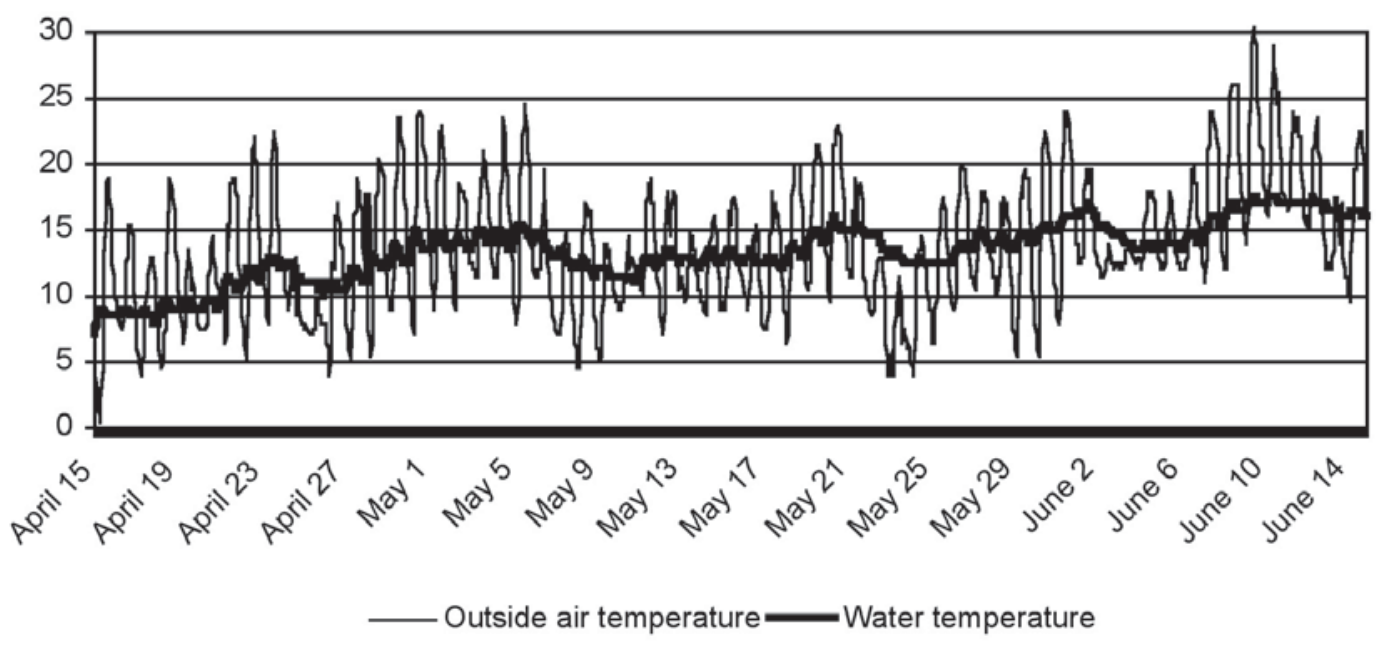

\section{Figure 1}

The course of water temperature and outside air temperature during experiments, measured every hour.

\section{Figure 1}

Température de l'eau et de l'air extérieur au cours des expériences, mesurées toutes les heures. 


\section{Data analysis}

Average values of the acquired parameters and SD were counted. Statistical significance was assessed using one-way analysis of variance (ANOVA, Statgraphics version 5), followed by Tukey HSD multiple range test comparisons. The difference between ovarian and pleopodal fecundity was tested by ANCOVA, using the female body length as a covariate. Linear regression was evaluated from the following parameters: ovarian and pleopodal fecundity, and number of juveniles at the $3^{\text {rd }}$ stage, and assessed with Statgraphics version 5. Probability values $<0.01$ were considered to be significant.

\section{Results}

\section{Ovarian fecundity}

The body length and weight of 20 mature females used in the experiment was $54.1 \pm 12.64 \mathrm{~mm}(43-93 \mathrm{~mm})$ and $5.08 \pm 5.16 \mathrm{~g}(2.24-23.37 \mathrm{~g})$, respectively.

The mean ovarian fecundity was found to be $130.8 \pm 107.6$, ranging from 46 to 505 eggs. The ovarian fecundity showed a linear relationship $\left(r^{2}=0.9042, P<0.0000\right.$ to the body length (Figure 2). The average size of eggs was found to be $1.2 \pm 0.2 \mathrm{~mm}(0.9-$ $1.7 \mathrm{~mm}$ ). We did not find any significant relationship between the size of eggs and their number. Respective to the size of females, however, the largest females had a higher number of the biggest eggs (1.6-1.7 mm), and had also the highest values of GSI (6.45$7.74 \%)$. The average gonadosomatic index of females was found to be $4.2 \pm 1.8 \%(0.83-$ $7.74 \%)$.

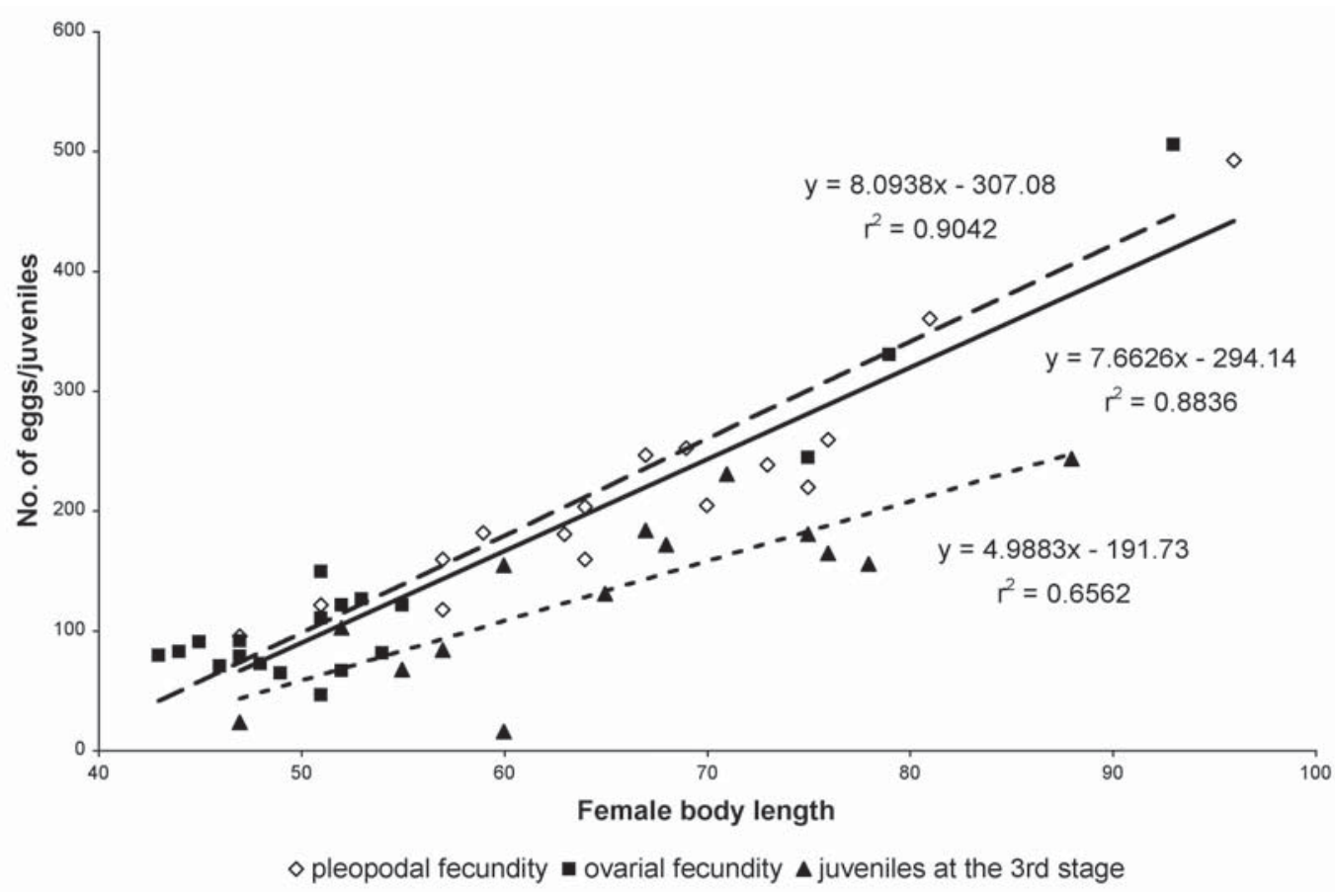

Figure 2

The relationship between the body length and ovarian fecundity, pleopodal fecundity, and production of juveniles at the 3rd stage in spiny-cheek crayfish females (Orconectes limosus).

Figure 2

Relation entre la fécondité ovarienne et pléopodale et la production de juvéniles au stade 3, chez l'écrevisse américaine (Orconectes limosus). 


\section{Pleopodal fecundity}

The body length and weight of 16 females used in the experiment was $66.8 \pm 11.68 \mathrm{~mm}$ $(47-96 \mathrm{~mm})$ and $10.86 \pm 6.86 \mathrm{~g}(3.10-29.91 \mathrm{~g})$, respectively. The mean pleopodal fecundity was found to be $217.8 \pm 94.9(95-492)$ eggs. The pleopodal fecundity again showed a linear relationship $\left(\mathrm{r}^{2}=0.8836, \mathrm{P}<0.0000\right)$ to the body length (Figure 2$)$. The estimated pleopodal fecundity was $10 \%$ lower than the estimated ovarian fecundity calculated by the resulting linear equations. However, we did not find a significant difference between ovarian and pleopodal fecundity when tested by ANCOVA using size as a covariate.

The proportion of eggs placed on each pairs of pleopods and results of the pairwise comparison between different pairs are shown in the Table 1. We found a statistically significant difference $(P<0.01)$ between the egg numbers carried on individual pairs of pleopods. The highest numbers of eggs were placed on the $3^{\text {rd }}$ and $4^{\text {th }}$ pair of pleopods with $53.1 \pm 23.1(25-122)$ and $59.0 \pm 24.1(28-117)$ eggs, respectively. Practically no eggs were placed on the $1^{\text {st }}$ pair of pleopods: $1.6 \pm 1.5(0-5)$ eggs. Altogether, $15.2 \pm 7.8(1-31)$ eggs were attached directly to the abdomen cuticle. The average size of eggs attached to the pleopods was $1.8 \pm 0.21 \mathrm{~mm}(1.45-2.15 \mathrm{~mm})$. We did not find any relationship between the size of a female and the size of eggs.

\section{Table I}

Percentage of eggs carried on individual pairs of pleopods (different alphabetic superscripts show significant differences in pairwise comparison; $P<0.01$ ).

Tableau I

Pourcentage d'œufs incubés sous chaque paire de pléopodes

\begin{tabular}{lccccccc}
\hline & $\mathbf{1}^{\text {st }}$ pair & $\mathbf{2}^{\text {nd }}$ pair & $\mathbf{3}^{\text {rd }}$ pair & $\mathbf{4}^{\text {th }}$ pair & $\mathbf{5}^{\text {th }}$ pair & Others & $\begin{array}{c}\text { Total no. } \\
\text { of eggs }\end{array}$ \\
\hline Average \pm STD & $1 \pm 0,6^{\text {e }}$ & $18 \pm 2,7^{\mathrm{C}}$ & $25 \pm 1,8^{\mathrm{ab}}$ & $27 \pm 2,4^{\mathrm{a}}$ & $22 \pm 3,2^{\mathrm{b}}$ & $7 \pm 2,7^{\mathrm{d}}$ & $\begin{array}{c}217,8 \pm \\
94,93\end{array}$ \\
\hline Min-Max & $0-2$ & $14-24$ & $21-27$ & $23-32$ & $16-27$ & $1-11$ & $95-492$ \\
\hline
\end{tabular}

Table II

The size of females, fecundity and egg/juvenile size (average and range).

\section{Tableau II}

Longueur des femelles, fécondité et taille des œufs/juvéniles (moyenne et amplitude).

\begin{tabular}{lccccccc}
\hline & & Females & & \multicolumn{2}{c}{$\begin{array}{c}\text { No. of eggs/ } \\
\text { juveniles }\end{array}$} & \multicolumn{2}{c}{ Egg/juvenile size } \\
\hline & No. & $\begin{array}{c}\text { body lenth } \\
(\mathbf{m m})\end{array}$ & $\begin{array}{c}\text { range } \\
(\mathbf{m m})\end{array}$ & average & range & $\begin{array}{c}\text { average } \\
(\mathbf{m m})\end{array}$ & $\begin{array}{c}\text { range } \\
(\mathbf{m m})\end{array}$ \\
\hline $\begin{array}{l}\text { Ovarian } \\
\text { fecundity }\end{array}$ & 20 & 54.1 & $43-93$ & 130.8 & $46-505$ & 1.2 & $0.9-1.7$ \\
\hline $\begin{array}{l}\text { Pleopodal } \\
\text { fecundity }\end{array}$ & 16 & 66.8 & $47-96$ & 217.8 & $95-492$ & 1.8 & $1.4-2.1$ \\
\hline $\begin{array}{l}\text { Juveniles at } \\
\text { the 3 }\end{array}$ & 14 & 65.6 & $47-88$ & 135.7 & $15-243$ & 7.1 & $6-8$ \\
\hline
\end{tabular}


Juveniles at the $3^{\text {rd }}$ stage

All 20 females laid eggs between April 22 and May 15. Six females lost eggs during the incubation. Juveniles hatched between June 11 and June 24, and moulted to the $3^{\text {rd }}$ stage between June 22 and July 4 . Total number of juveniles per female at the $3^{\text {rd }}$ stage (calculated from the values of 14 females which had not lost eggs) was $135.7 \pm 67.24$. The body length and weight of the 14 females was $65.6 \pm 10.92 \mathrm{~mm}(47-88 \mathrm{~mm})$ and $9.14 \pm 4.73 \mathrm{~g}(2.50-18.68 \mathrm{~g})$, respectively. The number of juveniles showed a positive correlation with the female body length $\left(r^{2}=0.6562, P<0.0004\right)$ (Figure 2$)$.

\section{Time of embryonic development}

The body length and weight of 80 mature females used in the experiment was $56.8 \pm 10.06 \mathrm{~mm}(41-82 \mathrm{~mm})$ and $5.91 \pm 5.60 \mathrm{~g}(2.10-17.91 \mathrm{~g})$, respectively. The time of laying was not dependent on the size of the female. We did not confirm that larger females extruded their eggs earlier. The disturbance also caused considerable losses of eggs during the incubation, especially if female was disturbed directly during the laying process. Only 43 females out of 80 females laid their eggs, and 26 of them reached the $1^{\text {st }}$ juvenile stage. The laying of females in this experiment took place between April 18 and May 16. Hatching of juveniles occurred between June 12 and June 27. The mean time from laying to hatching of juveniles at the $1^{\text {st }}$ stage was $46 \pm 3.8$ days (37-56 days), i.e. $647 \pm 39.9 \mathrm{CTU}(543-730 \mathrm{CTU})$. The water temperature slowly increased during the experiment from 8 to $17^{\circ} \mathrm{C}$. Females laying the eggs later had a lower requirement of CTU for embryonic development.

\section{DISCUSSION}

The higher fecundity of spiny-cheek crayfish in comparison with native European crayfish was confirmed. The ovarian fecundity of $130.8 \pm 107.63$ (46-505) oocytes per female is in agreement with our previous study (KOZÁK and POLICAR, in press). STYPIŃSKA (1973) presented an even higher average ovarian fecundity for the spinycheek crayfish, from 315 to 440 oocytes. Our results are comparable, however, if we take into account the size of females used in the experiments. The impact of spiny-cheek crayfish female size on fecundity has been confirmed by several studies, e.g. PIEPLOW (1938), STYPIŃSKA (1973), SCHULZ and ŚMIETANA (2001).

The literature data about average pleopodal fecundity of spiny-cheek crayfish are wide, ranging from 139 to 440 eggs per female, and there is always a large difference between minimum and maximum (altogether, the pleopodal fecundity ranges in the interval 35-555 eggs) (PIEPLOW, 1938; HOLDICH and LOWERY, 1988; STUCKI, 2002; HAMR, 2002). The pleopodal fecundity of $217.8 \pm 94.93$ (95-492) eggs recorded in our experiment is in agreement with the published data. We did not find a significant difference between ovarian fecundity and pleopodal fecundity observed just after laying when the results were corrected for female size. We can presume that the potential difference between ovarian fecundity and the number of pleopodal eggs at the end of embryonic development are caused mainly by losses of eggs during the incubation period. The magnitude of this difference may possibly reflect quality of environmental conditions. This phenomenon has already been observed in the spiny-cheek crayfish by PIEPLOW (1938), and by e.g. CELADA et al. (2005a,b) and SÁEZ-ROYUELA et al. (2005) in other crayfish species. We also recorded large variability in the fecundity of females of a comparable size, similarly to HARLIOĞLU et al. (2004).

The spiny-cheek crayfish has a higher average fecundity than native European crayfish, and comparable to non-native American species present in Europe. SAVOLAINEN 
et al. (1996) presented an average ovarian fecundity for the noble crayfish and signal crayfish of 166-264 oocytes with a minimum of 73 and maximum of 436 oocytes, and 377-456 (73-952) oocytes, respectively. They presented pleopodal fecundity of only 50$60 \%$ (max. 250 eggs) and 30-60\% (max. 466 eggs) of ovarian fecundity for the noble and the signal crayfish, respectively. These observations, however, were carried out in spring rather than close to the egg laying time. For the signal crayfish, CELADA et al. (2005a) presented an average pleopodal fecundity of up to 348 and 233 eggs at the beginning and at the end of embryonic development, respectively. STYPIŃSKA (1973) presented 130-325 and 210-345 oocytes for the noble crayfish and the narrow-clawed crayfish, respectively, dependent on the size of females. SCHULZ and ŚMIETANA (2001) presented that fully-matured female spiny-cheek crayfish had a considerably higher number of eggs than narrow-clawed crayfish of the same body length. This difference amounted to approx. 200 eggs for females of $9 \mathrm{~cm}$ length and 300 eggs for females of $11 \mathrm{~cm}$ length. LINDQVIST and LOUEKARI (1975) presented 248 oocytes for the noble crayfish. STUCKI (2002) presented the following average pleopodal fecundities per female: noble crayfish 150, stone crayfish 60, narrow-clawed crayfish 180 and signal crayfish 114 eggs per one female. MAGUIRE et al. (2005) founded a mean pleopodal fecundity of 62 eggs, ranging between 30 and 104 eggs, for the stone crayfish. The big eggs losses happen during the winter incubation among these crayfish species (CELADA et al., 2005a,b), which is a significant advantage for the spiny-cheek crayfish, which carries eggs for one to two months only in spring (as described already by ANDREWS, 1907).

BRINK et al. (1988) recorded ovigerous females of the spiny-cheek crayfish in their studied catchments from March to May. In our experiment, females carried eggs in April and May, and the mean time from laying to hatching was $46 \pm 3.8$ days (37-56 days, i.e. $647 \pm 39.9$ CTU (543-730 CTU). This is much lower than for the noble crayfish, where the estimated requirement for hatching in nature is approximately 240 days (1,500 CTU), (CUKERZIS, 1973; TAUGBØL and SKURDAL, 1990). MASSON (1977), HOFMANN (1980), WINNICKI et al. (2004), and CELADA et al. (2005a,b) stated that 906-1,380 CTU are needed for embryonic development in the signal crayfish, which is still higher than values recorded in our experiment for the spiny-cheek crayfish. The requirement of higher CTU for egg development in European crayfish in comparison with the spiny-cheek crayfish is evident even if we take into account the artificially shortened incubation times under laboratory conditions (HESSEN et al., 1987; PÉREZ et al., 1998; CARRAL et al., 2004; POLICAR et al., 2004).

The number of juveniles reaching the $3^{\text {rd }}$ stage was also high (136 juveniles) in comparison with the noble crayfish and the signal crayfish at the $2^{\text {nd }}$ stage (stage of independence). However, the number of juveniles in the $2^{\text {nd }}$ or $3^{\text {rd }}$ stage per female under laboratory conditions is mainly related to rearing conditions, so the differences of such values among various studies are difficult to interpret. In our previous study, under similar experimental conditions we obtained values of 47-97 and 133 juveniles at the $2^{\text {nd }}$ stage for the noble crayfish (POLICAR and KOZÁK, 2002, POLICAR et al., 2004) and the signal crayfish (POLICAR and KOZÁK, 2002), respectively.

\section{ACKNOWLEDGEMENTS}

We are grateful to Adam Petrusek and two anonymous reviewers for all the comments and suggestions that have helped improving the manuscript. This investigation was financially supported by the Czech Ministry of Education (project USB RIFCH No. MSM6007665809) and the Czech Science Foundation (projects 206/03/0532 and 206/03/D064). 


\section{REFERENCES}

ABRAHAMSSON S.A.A., 1971. Density, growth and reproduction in populations of Astacus astacus and Pacifastacus leniusculus in an isolated pond. Oikos, 22, 373-380.

ANDREWS E.A., 1907. The young of the crayfishes Astacus and Cambarus. Smithsonian Contribution to Knowledge. Part of Volume XXXV, No. 1718. Smithsonian Institution. Washington. $79 \mathrm{p}$.

AUSTIN C.M., 1998a. A comparison of clutch and brood size in the Red Claw, Cherax quadricarinatus (von Martens) and the Yabby, C. destructor Clark (Decapoda: Parastacidae). Aquaculture, 167, 135-145.

AUSTIN C.M., 1998b. Intraspecific variation in clutch and brood size and rate of development in the yabby, Cherax destructor (Decapoda: Parastacidae). Aquaculture, 167, 147159.

BRINK F.W.B., VELDE G., GEELEN J.F.M., 1988. Life history parameters and temperaturerelated activity of an American crayfish, Orconectes limosus (Rafineque, 1817) (Crustacea, Decapoda), in the area of the major rivers in The Netherlands. Arch. Hydrobiol., 114, 2, 275-289.

CARRAL J.M., PÉREZ J.R., CELADA J.D., SÁEZ-ROYUELA M., MELENDRE P.M., AGUILERA A., 2004. Effects of dead egg removal frequency on stage 2 juvenile production in artificial incubation of Austropotamobius pallipes Lereboullet. Bull. Fr. Pêche Piscic., 372-373, 425-430.

CELADA J.D., ANTOLÍN J.I., CARRAL J.M., SÁEZ-ROYUELA M., RODRÍGUEZ R., 2005a. Successful sex ratio of $1 \mathrm{M}: 4 \mathrm{~F}$ in the astacid crayfish Pacifastacus leniusculus Dana under captive breeding conditions. Aquaculture, 244, 89-95.

CELADA J.D., ANTOLÍN J.I., CARRAL J.M., PÉREZ M., SÁEZ-ROYUELA M., 2005b. Reproductive efficiency of the signal crayfish (Pacifastacus leniusculus Dana. Astacidae) at different densities under both culture and laboratory conditions. Aquaculture, in press.

CUKERZIS J.M., 1973. Biologische Grundlagen der Methode der kunstlichen Aufzucht der Brut dese Astacus astacus L.. Freshwater Crayfish, 1, 187-202 (in German with English abstract).

HAMR P., 2002. Orconectes. In: D.M. HOLDICH (ed), Biology of Freshwater Crayfish. pp. 585-608. Blackwell Science Ltd., London.

HARLIOĞLU M.M., BARIM Ö., TÜRKGÜLÜ I., HARLIOĞLU G.A., 2004. Potential fecundity of an introduced population, Keban Dam Lake, Elaziğ, Turkey, of freshwater crayfish, Astacus leptodactylus leptodactylus (Esch., 1852). Aquaculture, 230, 189-195.

HESSEN D.O., TAUGBØL T., FJELD E., SKURDAL J., 1987. Egg development and lifecycle timing in the noble crayfish (Astacus astacus). Aquaculture, 64, 77-82.

HOBBS H.H., 1974. Synopsis of the Families and Genera of Crayfishes (Crustacea: Decapoda). Smithsonian Contributions to Zoology, 164, 33 p.

HOFMANN J., 1980. Die Flußkrebse/Freshwater Crayfish. 2. Auflage (von K.M. Strempel). Paul Parey, Hamburg, 110 p. (in German).

HOLDICH D.M., ACKEFORS H., GHERARDI F., 1999. Native and alien crayfish in Europe: Some conclusions. In: F. GHERARDI, D.M. HOLDICH (eds), Crayfish in Europe as alien species. How to make the best from a bad situation? A.A. Balkema, Rotterdam, Brookfied, 281-292. 
HOLDICH D.M., LOWERY R.S., 1988. Freshwater Crayfish Biology, Management and Exploitation. Chapman \& Hall, London \& Sydney, Timber Press, Portland, Oregon, $498 \mathrm{p}$.

HUBER M.G.J. and SCHUBART C.D., 2005. Distribution and reproductive biology of Austropotamobius torrentium in Bavaria and documentation of a contact zone with the alien crayfish Pacifastacus leniusculus. Bull. Fr. Pêche Piscic., 376-377, 759776.

JONES C.M., 1995. Production of juvenile redclaw crayfish, Cherax quadricarinatus (von Martens) (Decapoda, Parastacidae) I. Development of hatchery and nursery procedures. Aquaculture, 138, 221-238.

KOZÁK P., POLICAR T., Annual course of gonad development in Orconectes limosus. Freshwater Crayfish, 15, in press.

KOZÁK P., POLICAR T., ĎURIŠ Z., 2004. Migration ability of Orconectes limosus through a fishpass and notes on its occurrence in the Czech Republic. Bull. Fr. Pêche Piscic., 372-373, 367-373.

KOZUBíKOVÁ E., PETRUSEK A., ĎURIŠ Z., KOZÁK P., GEIGER SH., HOFFMANN R., OIDTMANN B., 2006. The crayfish plague in the Czech Republic - Review of recent suspect cases and a pilot detection study. Bull. Fr. Pêche Piscic., 380-381, 13141324.

LEONARD B.V., LENNARD W.A., KILDEA D.G, 2001. A method for testing the effectiveness of artificial incubation of eggs vs. maternal brooding in the freshwater crayfish Cherax destructor (Decapoda: Parastacidae). Aquaculture, 195, 299-309.

LEWIS S.D., 2002. Pacifastacus. In: D.M. Holdich (ed), Biology of Freshwater Crayfish, Blackwell Science Ltd., London, 511-540.

LEWIS S.D., HORTON H.F., 1997. Life history and population dynamics of signal crayfish, Pacifastacus leniusculus, in Lake Billy Chinook, Oregon. Freshwater Crayfish, 11, 34-53.

LINDQVIST O.V., LOUEKARI K., 1975. Muscle and hepatopancreas weight in Astacus astacus L. (Crustacea, Astacidae) in the trapping season in Finland. Ann. Zool. Fennici, 12, 237-243.

MAGUIRE I., KLOBUČAR G.I.V., ERBEN R., 2005. The relationship between female size and egg size in the freshwater crayfish Austropotamobius torrentium. Bull. Fr. Pêche Piscic., 376-377, 777-785.

MASON J.C., 1977. Artificial incubation of crayfish eggs (Pacifastacus leniusculus Dana). Freshwater Crayfish, 3, 119-132.

MAZLUM Y., EVERSOLE A.G., 2004. Observations on the life cycle of Procambarus acutus acutus in South Carolina culture ponds. Aquaculture, 238, 249-261.

NAKATA K., GOSHIMA S., 2004. Fecundity of the Japanese crayfish, Cambaroides japonicus: ovary formation, egg number and egg size. Aquaculture, 242, 335-343.

ORZECHOWSKI B., 1984. Productivity of the freshwater crayfish Orconectes limosus Raf. (= Cambarus affinis Say) in Koronowo Basin. Acta Univ. Nicolai Copernici Prace Limnol. (in Polish), 14, 13-36.

PÉREZ J.R., CARRAL J.M., CELADA J.D., SAEZ- ROYUELA M., ROMERO M.P., 1998. Effects of different thermal treatments during embryonic development on the artificial incubation efficiency of crayfish (Austropotamobius pallipes Lereboullet) eggs. Control of the embryogenetic duration and implications for commercial production. Invertebrate Reproduction and Development, 34, 253-258. 
PETRUSEK A., FILIPOVÁ L., ĎURIŠ Z., HORKÁ I., KOZÁK P., POLICAR T., ŠTAMBERGOVÁ M., 2006. Distribution of the invasive spiny-cheek crayfish (orconectes limosus) in the Czech Republic - past and present. Bull. Fr. Pêche Piscic., 380-381, 903-918.

PIEPLOW U., 1938. Fischereiwissenschaftliche Monographie von Cambarus affinis Say. Zeitschr. Fisherei, 36, 349-440.

POLICAR T., KOZÁK P., 2002. Metody líhnutí a odchovu raků. (Methods of crayfish hatching and rearing) In: B. VYKUSOVÁ (ed.): Proc. conf. Produkce násadového materiálu ryb a raků (Hatchery production of fish and crayfish stocks), Vodňany, 63-71.

POLICAR T., SIMON V., KOZÁK P., 2004. Egg incubation in the noble crafish (Astacus astacus L.): the effect of controlled laboratory and outdoor ambient condition on hatching success, growth and survival rate of juveniles. Bull. Fr. Pêche Piscic., 372$373,411-423$.

REYNOLDS J.D., 2002. Growth and reproduction. In: D.M. HOLDICH (ed.), Biology of Freshwater Crayfish, Blackwell Science Ltd., London, 152-191.

SÁEZ-ROYUELA M., CARRAL J.M., CELADA J.D., MELENDRE P.M., AGUILERA A., 2005. Comparison between individual and group mating of Austropotamobius pallipes under controlled conditions. Bull. Fr. Pêche Piscic., 376-377, 699-704.

SAVOLAINEN R., WESTMAN K., PURSIAINEN M., 1996. Fecundity of Finnish noble crayfish, Astacus astacus L., and signal crayfish, Pacifastacus leniusculus, in various natural habitats and in culture. Freshwater Crayfish, 11, 319-338.

SCHULZ R., ŚMIETANA P., 2001. Occurrence of native and introduced crayfish in northeastern Germany and northwestern Poland. Bull. Fr. Pêche Piscic., 361, 629641.

SINT D., FÜREDER L., 2004. Reintroduction of Astacus astacus L. in East Tyrol, Austria. Bull. Fr. Pêche Piscic., 372-373, 301-314.

SMITH D.G., 1981. Life history parameters of the crayfish Orconectes limosus in Southern New-England USA. Ohio J. Sci., 81, 169-172.

SÖDERBÄCK B., 1995. Replacement of the native crayfish Astacus astacus by the introduced species Pacifastacus leniusculus in a Swedish lake: possible causes and mechanisms. Freshwater Biology, 33, 291-304.

STUCKI T.P., 2002. Differences in live history of native and introduced crayfish species in Switzerland. Freshwater crayfish, 13, 463-476.

STYPIŃSKA M., 1973. The fecundity of three types of crayfish inhabiting Polish waters. Rocz. Nauk Rol., 95 (1), 147-156 (in Polish).

TACK P.I., 1941. The life history and ecology of the crayfish Cambaris immunis Hagen. Amer. Midl. Nat., 25, 420-466.

TAUGBØL T., SKURDAL J., 1990. Reproduction, moulting and mortality of female noble crayfish, Astacus astacus (L., 1858), from five Norwegian populations subjected to indoor culture conditions (Decapoda, Astacoidea). Crustaceana, 58, 113-123.

WINNICKI A. PAWLOS D., FORMICKI K., ŚMIETANA P., 2004. On selected morphomechanical characteristics of signal crayfish (Pacifastacus leniusculus Dana) eggs during incubation. Bull. Fr. Pêche Piscic., 372-373, 431-438. 
